\title{
PROMOTING ENVIRONMENTAL AWARENESS TO UNDERPRIVILEGED CHILDREN IN JAKARTA BY HOLDING A SPECIAL EVENT “THE JOY OF CHILDREN 2016”
}

\author{
Magdalena Fenisia Caroline, Anastasia Maria Sri Redjeki \\ STIKOM - The London School of Public Relations Jakarta \\ fenisiacarolin@gmail.com, kikisoewarso@yahoo.com
}

\begin{abstract}
Lack of awareness to the urgency of environmental issues, especially those related to water pollution, has become one of the reasons among underprivileged children in Jakarta for not conserving the environment because it is not really a matter for them. They are not aware about the correlation between how people affect the water quality and the damages caused to marine environments. To cope with the water pollution issue, it is important to enact educational programs for them so they can be informed of how to conserve water, have proper hygiene, and maintain sanitation. Therefore, the writer created a pilot project focusing on underprivileged children in Jakarta to promote awareness of water pollution by holding a special event "The Joy of Children 2016" Generasi Pelindung Air on 6th and 7th August 2016 at Cakung and Cilincing, areas in the outskirts of Jakarta. It was supported by WWF Indonesia Panda Mobile, SiDalang (Kreasi Daur Ulang), and WatSan Action - Yayasan Tirta Lestari who took part as the educators for the event. By using human-centered approach in special event concept, the writer conducted the workshop at where the problem is, by walking a tour through the community to identify and highlight the problem, to have a discussion, and to play a game with the experts. It was successfully held and the objective of the event was not only achieved for the children participant but also for the committee.
\end{abstract}

Keywords: Special Event, Environmental Awareness, Water Pollution Issue, Underprivileged Children, Non-Governmental Organization, Public Relations 


\section{INTRODUCTION}

As the capital city of Indonesia and home to the Indonesian government, Jakarta is the most populous city in the country, and some people tend to earn relatively higher income. It is a place where most of the big businesses are in Indonesia. Unfortunately, the behavior patterns of the resident and business industries are inhospitable with the environment. It is causing substantial ongoing pollution problems, such as the harmful behavior for varied products from natural resources, like fuel and groundwater consumption; and the increasing of industrial disposal whether liquid, solid or gas.

Following the calculation results from the Ministry of Environment and Forestry Indonesia, in Jakarta, the index of the water pollution has taken the first place 41,51 percent rather than with the index of the land use 22,75 percent; and the air pollution is 34,71 percent. The result showed that the water resources in Jakarta, which the river, lake, and groundwater already heavily polluted.

According to the "Jakarta Environmental Status 2014" report published in March 2015 by the Jakarta Environmental Management Body (BPLHD), Jakarta's river had a horrible quality starting from upstream to downstream whether it is physical, chemical, and biological conditions. Only one percent is in good condition. The rest is 32 percent in heavy, 44 percent in the medium, and 23 percent in the light polluted condition (see Figure 1). Even worse, for groundwater quality is 99 percent in the light polluted state and 1 percent in medium (see Figure 2). In addition, the quality of the lake is 72 percent in medium and 28 percent in heavy polluted condition (see Figure 3). It means all the water resources in Jakarta were in dangerous conditions, especially for the groundwater and lake that totally had zero percent in a good condition.

Figure 1

River Pollution Index in Jakarta 2014

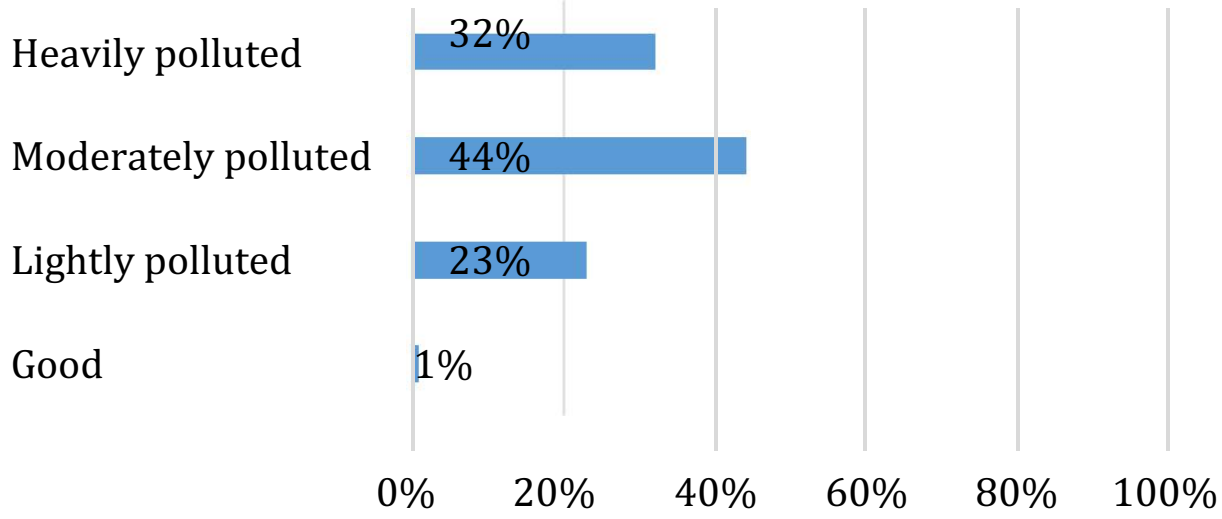

Source : Laporan Status Lingkungan Hidup Jakarta, BPLHD, 2014 
Based on the research result from Department of Public Works (PU) Jakarta and Japan International Cooperation Agency (JICA) in 1989 mentioned that

"The overall amount of wastewater in Jakarta is estimated at $1.316 .113 \mathrm{~m} 3 /$ day, which for domestic 1.038.205 m 3/day, office and commercial area 448.933 $\mathrm{m} 3 /$ day, and industry $105.437 \mathrm{~m} 3 /$ day. Regarding the number, domestic wastewater contributes to about 75 percent, office and commercial area 15 percent, and industry only around 10 percent. Thereby domestic wastewater and sewage office are the largest contributor to water pollution in Jakarta."

Jakarta are heavily polluted by gray water from households, commercial buildings, together with discharges from industries, pesticide and fertilizer run-off from agricultural land, solid waste, and fecal matter from overflowing or leaking septic tanks" (United Nation University, 2015).

According to a study by BPLHD (2014), most of the groundwater in Jakarta had colli bacteria beyond the specified quality. Within the highest of colli bacteria is in North Jakarta that 70 percent at improper and 30 percent at qualified. While for the other areas of Jakarta still got a better percentage, within around 50 percent to 50 percent.

The primary sources of groundwater pollution are 70 percent come from domestic waste, such as garbage and household sewage. Another cause that public should consider is the leaking sanitation disposal system. With the high population density in Jakarta causing the location of many wells adjacent to the septic tank. For this reason, there are many groundwater has been polluted by the leaking sanitation disposal system. From the monitoring result of BPLHD (2013), there are 46 wells below 10 meters ( 46 percent), 35 wells over 10 meters (35 percent), and 17 wells with nothing information obtained (19 percent). Thus, will have an adverse impact on public health due to the contamination and poor sanitation.

Most of the rivers in Jakarta also have the same condition that is heavily polluted. According to the rivers inventory from BPLHD (2014), Jakarta has 19 rivers with the longest river is Ciliwung River. Ciliwung has 46,20 km length, 70 meters' width, and 20 meters' depth. As the main artery of Jakarta, the preservation of Ciliwung River is crucial to be maintained. Unfortunately, based on the laboratory analysis results shown that all over the Ciliwung River has high Biochemical Oxygen Demand (BOD). The maximum BOD concentrate is in the Pluit roadway (BPLHD, 2014, p.58).

Biochemical Oxygen Demand (BOD) is a characteristic that indicates the amount of dissolved oxygen required by microorganisms (usually bacteria) to break down or decompose organic matter under aerobic conditions (Umaly and Cuvin, 1988). BOD examination is needed to determine the burden of pollution due to wastewater and to design biological treatment system (G. Alerts and SS Santika, 1987). If the BOD value is 
getting higher, then the water quality will get lower. In addition, it will increase the mud that caused the river to become shallower.

Domestic and industrial wastes are the causation for those high BOD value. According to the Vice Governor of DKI Jakarta, Djarot Saiful Hidayat (2015), 13 big rivers in Jakarta have contained at least around 356 tons of trash. Ciliwung River has the most amounting 132 tons of trash, followed by Krukut (44 tons), Pesanggrahan ( 24 tons), and Cipinang (33 tons).

A representative from the Landing Crumb Rubber (LCR) team, Serda Waris (2015), also mentioned that there are various kinds of garbage in the Ciliwung River, ranging from plastic trash, baby diapers, cupboard rack, sleeping bed, and even a refrigerator. Additionally, he stated that many trash pickers use rafts to find used plastic bottles in the river to be sold again. Djarot unsurprisingly states Jakarta is in a difficult emergency related with garbage.

According to the Government Rule No. 82 Year 2011, the standard quality of a Class-II river is only allowed to have a maximum fecal coliform of 1.000/100 mL. According to the report analysis of BPLHD (2014), coliform bacteria has its highest concentration in East and South Jakarta. East Jakarta with the highest pollution level is situated at Situ Rawa Badung (19.000.000/100 mL) and South Jakarta at Situ Mangga Bolong $(30.000 .000 / 100 \mathrm{~mL})$. Almost all other regions have higher than average concentration of coliform bacteria. The higher the level of coliform bacteria, the more the water source becomes unreliable for farming, fishery, recreational facilities, and plants.

As has already been indicated, all the water resources in Jakarta are heavily polluted whether from domestic and industry waste, plastic rubbish, and poor sanitation. Jakarta's citizens are not recommended to consume the water from those three water resources. However, poor households have limited knowledge on the issue and not sufficiently better access to piped water.

The public water company in Jakarta is PDAM DKI Jakarta - PAM Jaya. They provide clean water to its two partners; for the West area is managed by PT Pam Lyonaise Jaya (PALYJA) and for the East area is managed by PT Aetra Air Jakarta (Aetra). As a mediator and regulator between the three parties, since November 2001, the government established Jakarta Water Supply Regulatory Body (JWSRB). It is an independent and professional institution to maintain balanced interest between public, the cooperating parties, and Jakarta's government to undertake water service provision in the DKI Jakarta. 
Figure 2

The Governance of the Jakarta Water

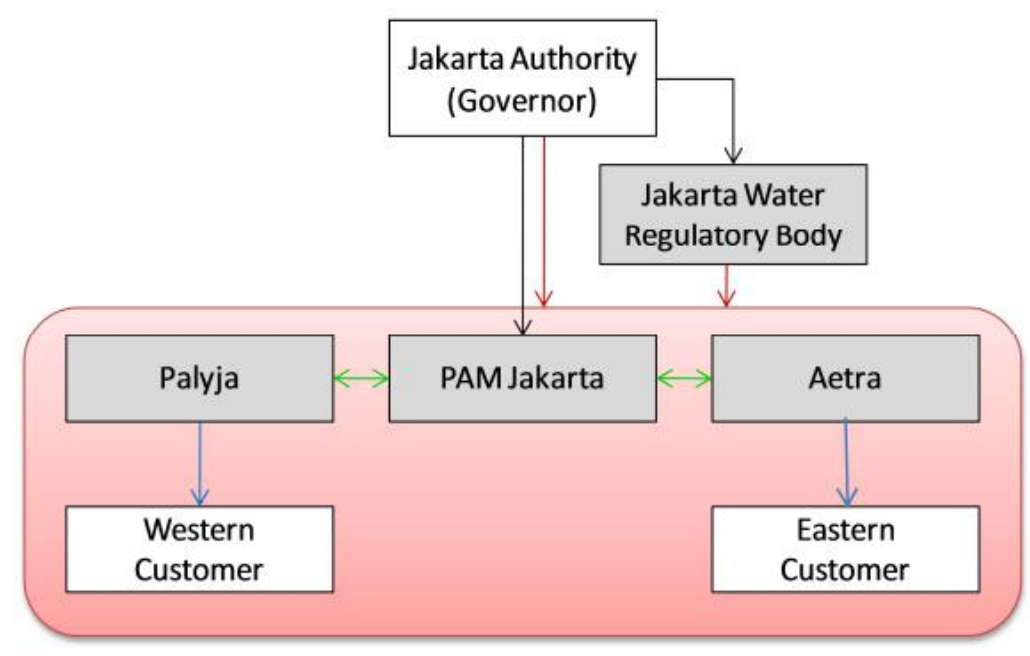

Source : Jakarta Water Governance, Nugroho, p.4

Regarding the water sources, piped water distributed by those two operators, was sourced from Jatiluhur Dam in West Java, Ciliwung River, Pluit weir and several other rivers. The biggest contribution is from Jatiluhur Dam (Fiona Zakaria, 2009). Every year the production of clean water by PAM Jaya cannot meet the needs of Jakarta's citizens. In 2012, production of PAM Jaya amounted to 488.46 million M3 and in 2013 amounted to 537.02 million M3.

Although, the clean water production by PAM Jaya has increased, unfortunately, the water consumption from residents of Jakarta also got intense. Water consumption in Jakarta in 2013 amounted to 943.97 million M3 when compared with the consumption in 2014 amounted to 970.99 Million M3, so there was an increase in water consumption in Jakarta at 27.02 Million M3.

In addition, PAM Jaya is still struggling to reduce water losses, known as non-revenue water (NRW). North Jakarta was the highest region with 46 percent of water loss. Mohamad Selim, President Director of Aetra stated that 80 percent of NRW was a result of old and rusty pipes, while the other 20 percent was because of water theft. The company had to spend around Rp 36 billion just to reduce for one percent of the NRW, while it could be serve for 12.000 new customers. It was difficult for them to destroy the water theft.

If people consume from polluted water, it can effect on their body. In 2013, the three main diseases happened in Jakarta were influenza with 712.541 people, hypertension with 222.982 people, and diarrhea with 174.018 people (BPLHD, 2014, p.588). Based on that data, it was true that diarrhea took in the third place, but we cannot underestimate it. World Health Organization (WHO, 2013) mentioned, "Diarrhea disease is a leading cause 
of child mortality and morbidity in the world, and mostly results from contaminated food and water sources. Worldwide, 780 million individuals lack access to improved drinkingwater and 2.5 billion lack improved sanitation" (para.6). In addition, diarrhea tended to be higher in the group of low education and worked as a farmer, fisherman, and laborer (Ministry of Health, 2011). Therefore, to reduce health risks, people in Jakarta, especially the poor household need to be aware that consuming water from ground water and rivers are very not recommended.

The water pollution from those three water resources in Jakarta not only causing to the health risks, but also the to the sea pollution. All of the thirteen rivers in Jakarta will end up flowing into the ocean, where Thousand Island (Kepulauan Seribu) is located. As mentioned before, those rivers have contained at least around 356 tons of trash. Bambang Sugiyono, Vice Mayor of North Jakarta (2012) stated that there are 92 tons of waste flowing into the ocean every day. Based on the report from Solid Waste Management Agency (Dinas Kebersihan, n.d.) Jakarta, in 2007-2014, 11-15 percent of the waste is plastic, with producing 871 tons of plastic per day. That is one of the contribution that made Indonesia was the second biggest marine pollution in the world, producing 3,2 million tons of plastic waste, with 1,29 million tons of plastic waste flowing into the ocean, based on the research by Jenna Jambeck from Georgia University in 2010.

As the sea contaminated by trashes and waste, there appear some effects. First, the liquid sewage that keeps flowing to Jakarta Bay cannot be processed. It can affect the ecosystem by changing seawater $\mathrm{PH}$, reducing the water clarity, or even leading to the enrichment of nutrition in the sea that can cause the eutrophication in seawater that put the coral in danger (STEP, 2014).

Second, the plastic waste will have ended up into another little islands in Jakarta, that are Pari, Lancang, Payung, Pramuka, and Kelapa Islands. In the last, a new problem for all the world's major oceans including the Arctic and Antarctic, is known as 'micro plastics', the plastic waste that breaking down into smaller fragments, which can further damage to marine wildlife.

Micro plastics is invisible to the naked eye because it is just a few millimeters in diameter. According to the marine scientists, Karen Lavender Law and Richard Thompson (2014) stated that

Every single plastic items ultimately degrade into millions of micro plastics pieces. It is easily ingested by fish, mussels and other sea animals, and there is growing scientific evidence linking them to the passage of deadly, persistent chemicals through the environment, such as the pesticide DDT and toxic PCBs, making them more concentrated when they come into contact with marine life (para. 6).

Cleaning up the micro plastics in the ocean is difficult, as it is not feasible. However, if people do not care about this plastic waste in the ocean, then there will be a massive cause 
of injuries and deaths of numerous marine animals and birds. Therefore, education of a community about the problems of marine debris may help to prevent some of the problems, and education in schools can help not only the children to learn good habits but also can spread the knowledge to their families (Derraik, 2002).

BPLHD stated that the level of understanding of people in Jakarta has not seen quite well and equitably, so it is necessary to make efforts involving the public to increase the understanding how significantly the environment (2014, p.631), not to mention public awareness of water pollution in Jakarta is limited. Most of the non-government organization stand for the specific purpose related to the water issues. For example, WatSan Action - Yayasan Tirta Lestari concern in water pollution, but specific into the lack of sanitation effect. Then, there is Greeneration concern in water resources issue with specific into the plastic waste effect. Therefore, promoting environmental awareness in water pollution is needed as soon as possible.

The problems of water pollution are too complicated for people to understand, not to mention for children. The world is home to 1.8 billion children, where 22,7 million children between 10-14 years old live in Indonesia (BPS, 2010). The 10-14 years old bracket is the third largest age group in Indonesia after the group of 0-4 years old and 59 years old. Children matter because they are the shapers and leaders to the global future. Appropriate investment in today's children by educating them about water pollution will become a better preparation for the future.

Education is a human right that should be accessible to everyone, without any discrimination. Unfortunately, most of the children from disadvantaged environment are not able to enjoy their right to receive education. Lack of access to information makes them not too much aware of environmental issues. They are raised within impoverished environments where there are limited positive role models for appropriate social behaviors and living in the clean environment. While for the children from middle to highincome family, they have positive role models and better access from their well-educated parents. Therefore, underprivileged children are the earliest people who need the intervention.

If they are getting aware of the water pollution, it helps them to choose what should they do and not to do. They are living in slum areas where keeping the environment is not matter things for them. In addition, most of them have near access to the water resources. Their poor habitual on keeping the environment sustainability could exacerbate those water resources condition.

The easiest strategy and tactic for the underprivileged children to understand and be aware of water pollution is by holding a public relations event. Collaborating with experts, either individuals or organizations, is strongly needed to educate the kids in the event. The children must also have to be actively involved during the event. Doing 
activities will make them remember what they have learned remain longer in their memory.

Special event is a notable occasion arranged as a strategic part of public relations (Guth and Marsh, 2012). Public relations governs the communication contacts within the organization to create interconnections with all stakeholders of the organization (Caywood, 1997). Therefore, special event can be utilized as an extensive strategic tool to enhance public relations (Yolani, 2000).

The Joy of Children (JOC) is serial events for underprivileged children to enhance their knowledge on spesific issue. It is a special event once a year started at 2015 organized by Lecreatté. The JOC in 2015 was an edutainment about English, and now for this year, it will be about environment. Edutainment approach standing as a combination of education and entertainment. It is to promote the kids learning through exploration, interactivity, trial and error, that kids get so lost in the fun and do not realize they are learning at the same time.

\section{LITERATURE REVIEW}

A master's student at University of Southern California, Wanda Yolani Albano (2000), wrote a thesis entitled "Special Event Planning in the Non-Profit Sector" about a yearly fundraising event to eradicate women's cancers organized by the Cedars-Sinai Research for Women's Cancers. One of the objectives of Cedars-Sinai Research for Women's Cancers is to increase awareness amongst donors and attendees. The special event was a strategic public relations tool and tactic for the organizer to help fight the battle against cancers on women.

The objective of her thesis is to understand how special event could be successful in raising funds from the guests toward eradicating female types of cancer. The researcher used public relations strategic planning as a template to produce a successful special event. She found that creating a special event "An Unforgettable Evening 2000" with strategic planning method gave a huge success for Cedars-Sinai Research for Women's Cancers. There were 793 guests attended the event, and it generated \$1.7 million. It had conveyed many of their key messages and increased awareness amongst current and prospective donors. One significant advantage that Cedars-Sinai Research for Women's Cancers has is it already started in 1997, so they have their previous knowledge to create scenarios in avoiding a potential crisis.

Lecreatté organizes the Joy of Children (JOC) that focuses on educating disadvantaged children in Jakarta. The JOC is the exclusive trademark of their special annual event. The first special event was held on 21st November 2015 to improve the confidence of children 
in speaking English. Then, their next second event in 2016 will be made with the purpose of promoting environmental awareness of water pollution.

\section{METHOD}

This project are made with observatory and participative methode.

\section{RESULT AND ANALYSIS}

\section{Phase 1: Research}

Quantitative Pre-Event Research

DKI Jakarta is the densest populated province in Indonesia (BPS Jakarta, 2015, p.6). In 2014 , there are 10,8 million people where 720.966 children ( 367.534 boys and 353.432 girls) between 10-14 years old live in it (BPS Jakarta, 2016). The first place winner of the 2015 World Citizen Essay Contest, Zara Rupp stated that "over 41\% of Jakarta's population does not have a clean, reliable, or close water source. For example, most families have to walk several miles to reach their water source, and even when they get there it may still be dirty, contaminated, or unsafe" (2015, para. 6). Moreover, more than half of Jakarta population lacks safe water to drink. Many people are dying from water related problems, and it is having the biggest impact on children (Rupp, 2015). WHO and UNICEF Joint Monitoring Programme (2015) mentioned that every 90 seconds a child dies from a water-related disease. To cope with the water crisis, it is important to enact educational programs for the public about how to conserve water, proper hygiene and sanitation. Therefore, the project was to promote awareness of water pollution for the children in Jakarta.

\section{$\underline{\text { Five W's }}$}

a. Why

This special event was occurring because there is a lack of awareness of water pollution issue among underprivileged children. They didn't aware about the connection between human impacts to the water quality and damage to marine environments. Therefore, the compelling reason for conducting this event was to enhance their awareness of water pollution in Jakarta.

b. Who

The event was organized by Lecreatté, a non-government organization. The event was held for underprivileged children who are living in slum areas in Jakarta within the range age for $9-13$ years old. The participants were studying in the elementary school from third to sixth grade. The event stakeholders or educators were WWF Indonesia Panda Mobile, SiDalang (Kreasi Daur Ulang) Community, AIESEC UI, and WatSan Action - Yayasan Tirta Lestari. The sponsors were PT Citra 
Van Titipan Kilat, PT. Tupperware Indonesia, ERIGO Store, William Soeryadjaya Foundation, PT Indofood Sukses Makmur Tbk., and PT Tirta Investama. Lastly, the media partners were NET TV, kaWanku, Cosmo Girl, and Mother\&Baby Magazine.

c. When

The most convenient date for participants was after long holiday (Libur Lebaran) and at the first week of new semester. Therefore, the event was held on Saturday, 6th August 2016 and Sunday, 7th August 2016.

d. Where

The event should occur in slum areas in Jakarta. These places in Jakarta usually don't have access to clean drinking water, and sanitation and sewage are not services people get. Therefore, the participants that the writer was looking for are staying and surrounding by poor environment, such as so much garbage scattered. Based on the community research and visiting directly, the writer got two communities based in Cakung - East Jakarta and Cilincing - North Jakarta who were Cakung Children Community at Jalan Cempaka IV No. 16 and Yayasan Putri Kasih Cilincing at Jalan Kalibaru Timur VI-A No. 14.

e. What

The outcomes that the writer wish to achieve are the participants not only understand about keeping the environmental things that already told but also it will remain longer in their memory. Moreover, the outcomes that the writer had achieved were the participants realized about their habitual life will have impact to water problems, then they want to change theirselves to live more environmentally better as a generation of water conservative (Generasi Pelindung Air). Otherwise, the challenge of this project that turned out to be completely well are the funding.

\section{SWOT Analysis}

Once the five W's are determined, the writer used SWOT Analysis to understand all sorts of situations both from internal and external point of view. Here are the strengths and weaknesses of the project: 
Table 1

Strength and Weaknesses of the Joy of Children

\begin{tabular}{|c|c|}
\hline Strengths & Weaknesses \\
\hline $\begin{array}{l}\text { Environmental Issues are } \\
\text { becoming hot toplc nowadays }\end{array}$ & Poor medla efforts \\
\hline $\begin{array}{l}\text { Good potentlal for sponsors to } \\
\text { take a part of helping the } \\
\text { environment through education. }\end{array}$ & $\begin{array}{l}\text { Lecreatte hasn't legally establlshed } \\
\text { as non-pront organization } 80 \text { it } \\
\text { doesnt have a bank account }\end{array}$ \\
\hline $\begin{array}{l}\text { Soclal medla channels are } \\
\text { Increasingly being used as part of } \\
\text { overall plan }\end{array}$ & $\begin{array}{l}\text { Most of the people just notice the } \\
\text { name of the project, but not the } \\
\text { organization who made it }\end{array}$ \\
\hline $\begin{array}{l}\text { High skilled volunteers want to be } \\
\text { Involved }\end{array}$ & $\begin{array}{l}\text { Limited human resources, therefore } \\
\text { volunteer recruitment is needed to } \\
\text { follow up third party and as } \\
\text { administration stati. }\end{array}$ \\
\hline $\begin{array}{l}\text { Increasing focus on design and } \\
\text { content In the soclal medla }\end{array}$ & \\
\hline
\end{tabular}

Goldblatt has mentioned about the opportunities and threats are two key factors that generally present themselves either during an event or after it has occurred. However, the writer should think carefully about these factors to prevent the project for going the wrong way. 
Table 2

Opportunities and Threats of the Joy of Children

\begin{tabular}{|c|c|}
\hline Opportunittes & Threats \\
\hline Allgn with environmental cause. & $\begin{array}{l}\text { One of the communlity partner did } \\
\text { not execute withy the previous } \\
\text { agreement. }\end{array}$ \\
\hline Collaborating with other NGOs. & $\begin{array}{l}\text { The volunteer representation was on } \\
\text { a pro bono basis, so they could not } \\
\text { be full time worker. }\end{array}$ \\
\hline $\begin{array}{l}\text { Potential new followers on soclal } \\
\text { media channels. }\end{array}$ & $\begin{array}{l}\text { The weather was hotter that had } \\
\text { been estimated. }\end{array}$ \\
\hline Developing more loyal volunteers. & \\
\hline $\begin{array}{l}\text { The particlpants become } \\
\text { messengers and agent of change } \\
\text { to their surrounding environment } \\
\text { In the future. }\end{array}$ & \\
\hline
\end{tabular}

Source : Data processed by writer, 2016

\section{Phase 2: Design}

Brainstorming and Mind Mapping Activity

This project has two mentors since it was started in 2015 who are Sofia Blake and Zack Petersen. The writer did the group brainstorming session with them through email on March 18th - April 6th 2016. It was started very basically that the writer did the research about water pollution issue and wondering if they might have had ideas for linking it into the JOC. The writer was thinking it might be like a seminar and company visit, but still not sure.

Sofia responded with having no idea to advise, all she knew that the writer was on the right track. However, she gave two names to get attach with; Sano from Green Generation who is one of the most influental people in the environmental movement; and Lieselotte 
Heederik who heads an NGO that provides inexpensive filtering systems to have purified water. Sofia was wondering maybe they can be partners for JOC.

After Sofia, Zack responded the writer to have some research again. For instance, how many kids die every year as a result of the water in Jakarta being polluted? How many die from diarrhea? Why is that in a city of 13 million there is no potable drinking water? Zack told the writer to have something powerful...a powerful video about spending the night in the slums and how filthy the water is. Sofia agreed with that, she told the writer to do research and get numbers because we all know there is a problem, but lack of reliable research leaves people a lot of room to deny the problem. She suggested to start with interviews in communities, see if the writer can find another NGO that work on sanitation or communal health and ties water to health to children.

The writer always all ears to them and took action quite fast. Afterwards, the writer gave a report to them:

a. The writer has already contacted Sano by Whatsapp to be a speaker for an event, and he was still thinking about it.

b. The writer found two NGOs; SiDalang and WatSan Action - Yayasan Tirta Lestari in order to have a collaboration.

c. The writer already got 60 kids from three communities and foundations, and still looking to have more kids.

At that phase, the writer got an idea that JOC 2016 will have pre-event and main-event. The writer thought that the pre-event would be like asking AETRA or Palyja to do socialization for each communities and foundations about water theft and pollution. Then the main event would take place at Eco Park Ancol where there will be Sano speaking about water resources and problems in Jakarta, recycling workshop with SiDalang, and WatSan Action talking about sanitation and polluted water. After that, the participants will have free times to enjoy the Eco Park. However, that concept does not work in the end. The writer had tried to get in touch with people who works in Eco Park Ancol, and also already sent proposal to the Marketing team, but there was no any respond for one month, which was crucial and running out of time.

One day, the writer called Sofia Blake to tell her about the progress of JOC that the writer already had the children, the activities, and the main messages but still did not get the place for the event. Then Sofia asked a few simple questions like, why do you want to do that and what do you want. At that moment, we started a marvelous mind mapping activity.

Here is the problem with the project's original set up; the writer would spend a lot of resources - time, money and labor to organize an event with no clear deliverable at the end; the children actually do not need JOC to tell them about polluted water, they live in 
it; people know what they should do and what to avoid in terms of clean water, the problem is how to make them do it. Sofia continued, why wouldn't an event in which we engage kids in games or workshop that teach them about clean water and sanitation? How do you help children take actions that will lead them to make better choices? How do you help them get clean water, wash their hands and dispose of waste properly? Sofia and the writer concluded that asking them to come to Eco Park Ancol to play games for one afternoon may not be the best way.

The writer then decided instead of getting kids to Ancol, the JOC will come to the kids for conducting the workshop, where the problem is. There will be walking a tour through the community to identify and see the problem, having a discussion and game with the expertise. The writer need to do partnership with environmental organizations that have the expertise. This will be the prototype or pilot project in two kampungs. It will revisit and revise. The project 's new set up has become more human-centered.

However, while the writer already got S.A.J.A Foundation, Belajar Bersama Sjors Foundation, IPPA Rawamalang, Sobat Kolong, and Dilts Foundation, the writer got another challenge. Sobat Kolong and Dilts Foundations were not fit with the new concept because of their locations; Sobat Kolong located in the roadside which will dangerous for the kids to have walking through observation, otherwise Dilts Foundation located in a good residential that clean and well organized which there is no environmental problem we could find easily. Afterwards, the writer lost contact with IPPA Rawamalang and Belajar Bersama Sjors Foundation, there were no any respond from them after the last conversation. Lastly, S.A.J.A Foundation said sorry that they could not join because they just remembered that they already had a deal with students from Universitas Indonesia at the date JOC will be hold. In hindsight the writer realize that problem was actually good and safe the writer because the writer did not need many community partners, just two kampungs. Therefore, the writer went back to observe another community partners that have locations according to the new project's set up. The writer will emphasize this in the coordination phase.

\section{Basic Resource: Finance}

The event budget is the most important tool to manage the financial decisions in the event planning (Goldblatt, 2014, p. 141). Here is the event budget of the JOC 2016: 
Table 3

Event Budget Plan of JOC 2016

\begin{tabular}{|c|c|c|}
\hline NO & ITEM & AMOUNT (IDR) \\
\hline \multicolumn{3}{|c|}{ Printing } \\
\hline 1 & T-shirt & 10.000 .000 \\
\hline 2 & Handbook & 12.000 .000 \\
\hline 3 & Paper Bag & 3.750 .000 \\
\hline 4 & Certificate & 600.000 \\
\hline 5 & Plaque & 50.000 \\
\hline & Total Printing & 26.400 .000 \\
\hline \multicolumn{3}{|c|}{ Food \& Beverages } \\
\hline 1 & Food & 4.800 .000 \\
\hline \multirow[t]{3}{*}{2} & Beverages & 1.700 .000 \\
\hline & Total Food \& Beverages & 6.500 .000 \\
\hline & TOTAL BUDGET & 32.900 .000 \\
\hline
\end{tabular}

Source : Data processed by writer, 2016

Table 3

Event Budget Report of JOC 2016

\begin{tabular}{|c|c|c|c|}
\hline NO & ITEM & BUDGET & $\begin{array}{l}\text { ACTUAL } \\
\text { COST }\end{array}$ \\
\hline \multicolumn{4}{|c|}{ Printing } \\
\hline 1 & T-shirt (150 pcs) & 10.000 .000 & $\begin{array}{r}\text { Sponsored by } \\
\text { ERIGO }\end{array}$ \\
\hline 2 & Handoook (150 pcs) & 9.500 .000 & 9.500 .000 \\
\hline 3 & Paper bag (150 pcs) & 4.200 .000 & 4.200 .000 \\
\hline 4 & Certificate (110 pcs) & 700.000 & 700.000 \\
\hline 5 & Plaque (5 pcs) & 50.000 & 50.000 \\
\hline 6 & ID card and trash bin sticker & 150.000 & 150.000 \\
\hline 7 & Educational stickers (450 pcs) & 600.000 & 600.000 \\
\hline & Total Printing & 25.200 .000 & 15.200 .000 \\
\hline \multicolumn{4}{|c|}{ Content of Goodle Bag } \\
\hline 1 & Tolletrles (75 pax) & 1.200 .000 & 1.200 .000 \\
\hline 2 & Indomlk (80 pax) & 800.000 & 800.000 \\
\hline 3 & Tumbir (150 pcs) & 5.550 .000 & $\begin{array}{r}\text { Sponsored by } \\
\text { Tupperware }\end{array}$ \\
\hline 4 & Lunch Dox (75 pcs) & 9.375 .000 & $\begin{array}{l}\text { Sponsored by } \\
\text { Tupperware }\end{array}$ \\
\hline & Total Content of Goodle Bag & 16.925 .000 & 2.000 .000 \\
\hline
\end{tabular}




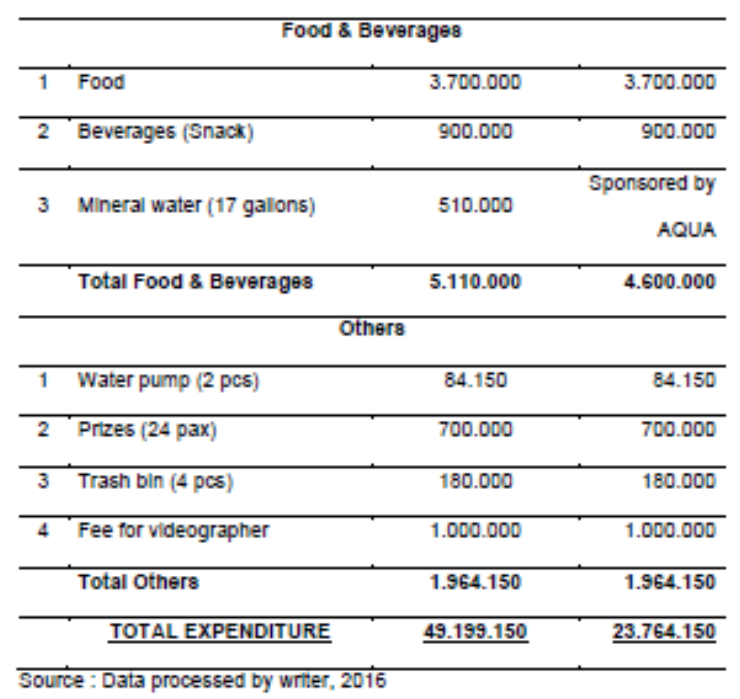

Figure 3

Waterfall Chart of Budget vs Actual Cost, from the writer, 2016

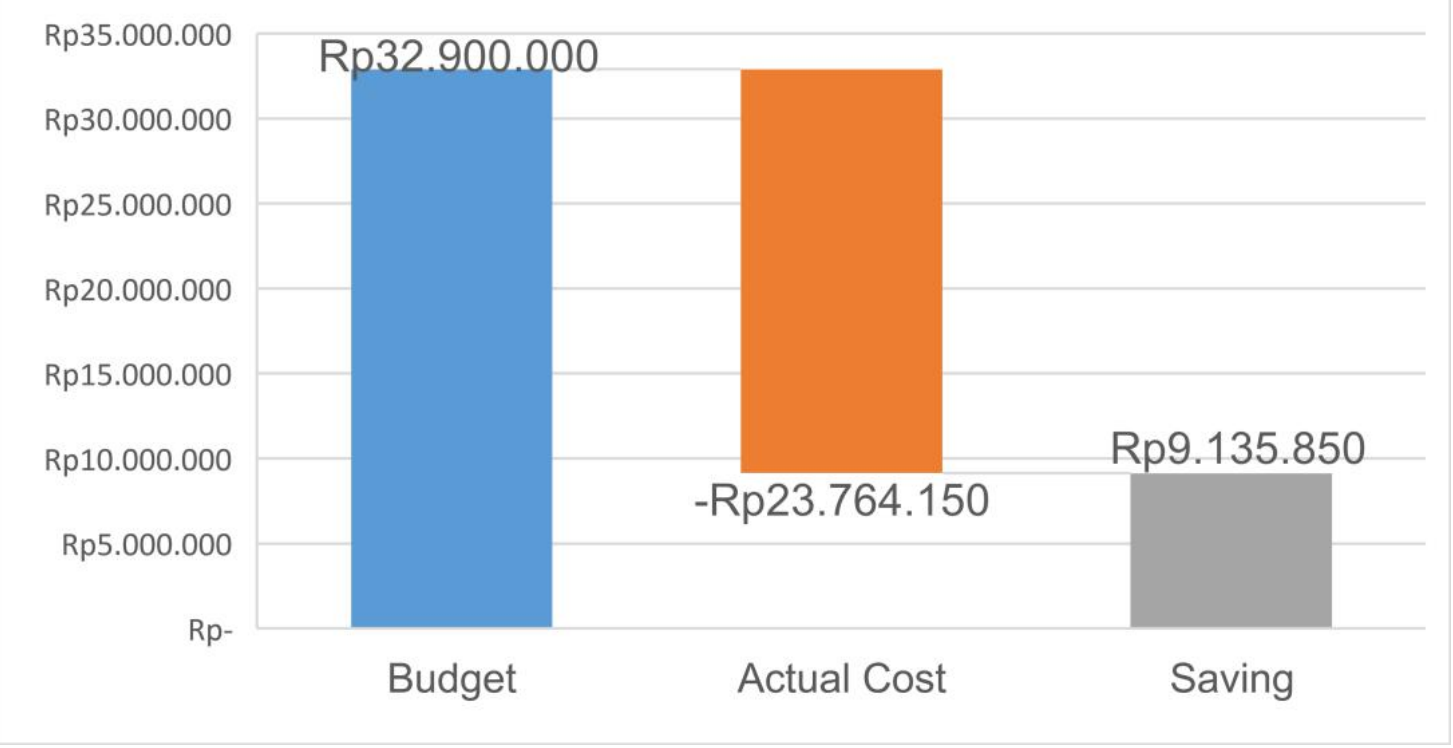

The budget planning is $\operatorname{Rp} 32.900 .000$, but the event's expenditure is Rp 23.764.150. It means the event had efficiency rate into $28 \%$. This could be a lesson for the writer to be more precisely when creating the next budget planning. 
Figure 4

Waterfall Chart of Sponsorship vs Expenditure, from the writer, 2016

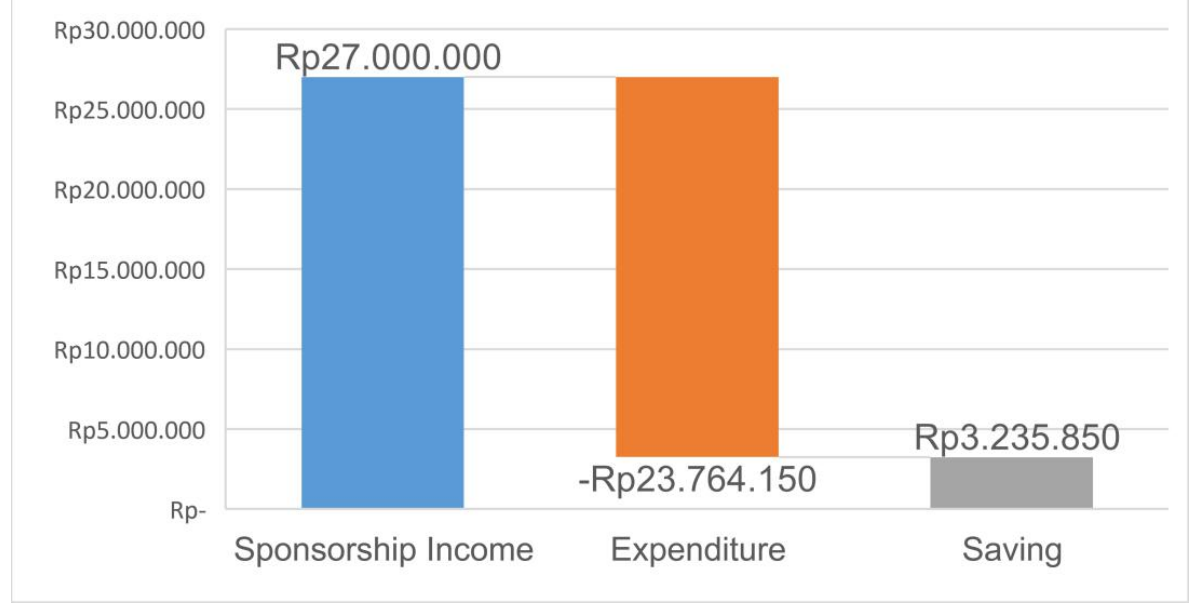

Next, the sponsorship income is Rp 27.000.000 but the event's expenditure is $\mathrm{Rp}$ 23.764.150, so then the event's balance is $\mathrm{Rp} 3.235 .850$. It means $11 \%$ from the sponsorship income can be stored for the next event.

\section{Basic Resource: Team}

Volunteers are the lifeblood of this project. Most of the volunteers in JOC are from university students who just graduated or will be graduated soon. They were recruited through online; by sending e-mail or registering in indorelawan.org. The first volunteer that the writer was looking for was a Graphic Designer. The writer spread the opportunity on Twitter, Facebook, and LINE@. Then, the writer got Frans Sitanggang, a student from State Polytechnic of Creative Media who was applied on February 25th by email. At that moment, there were not many good applicants like Frans, therefore the writer only accepted him and made a meeting afterwards. The result of a meeting with him was he would find his relatives to join volunteering as graphic designers too. After weeks, he got Chyntia Devin and Ahmad Syauqi who were also his best friends. This was good because they knew each other well and have the same taste of graphic designing.

The writer continued with looking a social media team. In the beginning, there were 75 applicants but the writer cut it off into 20 applicants only. The writer gave a social media test to that 20 persons, then in the end there were 6 best persons who get accepted. They were Syaza Sakinah, Visi Digita, Novia Indrianti, Puspa Giarini, Shinta Nurin, and Apriasih. However, in the middle of time Apriasih just got away without permission and nothing news came from her.

The writer needs people to help coordinate the volunteers in order to get focus with external things, therefore the writer made an opportunity for volunteers to be Event Coordinators (EC). The writer had two EC which were Patricia Djuhadi from Oregon State 
University - USA and Elisa Claudya from Pelita Harapan University. Their responsibility was completely in coordinate the human resources of JOC.

Next, the writer was looking for handbook and photography team. The writer opened the opportunity through indorelawan.org and it went well. For the handbook team there were Annisa, Mawar, Sherly, and Christin while in the photography team there were O, Hutama, Sari, and Nadira.

In the middle of time, the writer realized that graphic designer team had overload assignments, especially for social media contents. Thus, the writer opened an opportunity again looking for graphic designer team that specifically works for the social media contents. The writer got Cathlin, Fransiska, and Maria.

Figure 5

Organizational Structure of JOC, from the writer, 2016

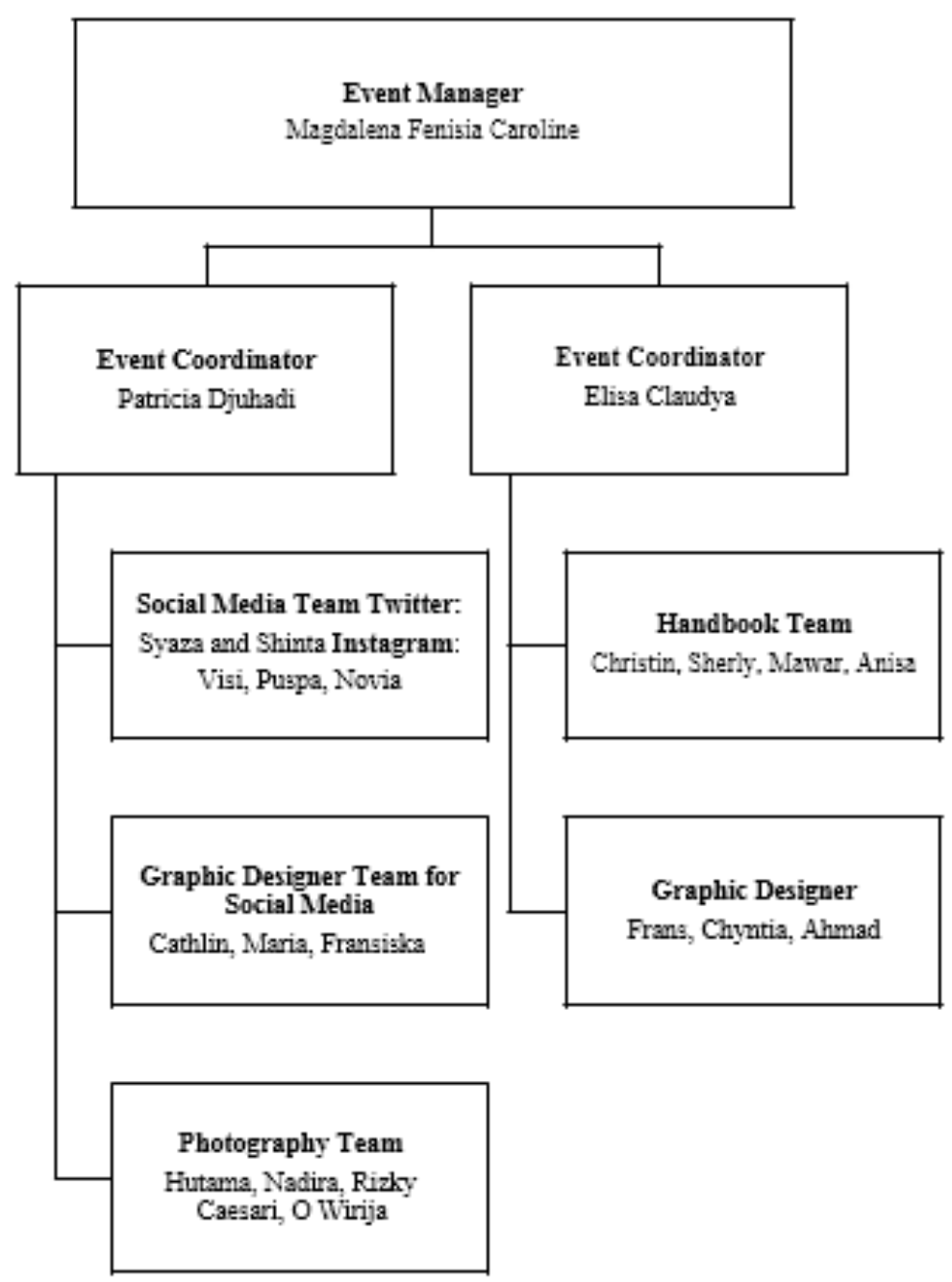

Not all volunteers could come to the event itself, therefore the writer did volunteering recruitment again to get some help in the event. Here is the job description for volunteers: 
Table 4

Job Description of Volunteers JOC 2016 (Pre-Event)

\begin{tabular}{|c|c|}
\hline Position & Job Description \\
\hline Event Manager & $\begin{array}{l}\text { 1. Concept creator and responsible from the } \\
\text { pre-event untl after the event. } \\
\text { 2. Fully responsible in financlal management, } \\
\text { sponsor and medla partnership, } \\
\text { community partnership, and supporting } \\
\text { partnership. } \\
\text { 3. Recruiting volunteers. } \\
\text { 4. Taking big roles as content writer of soclal } \\
\text { 5. Editor of Handoook JOC } 2016 \text {. } \\
\text { 6. Handling printing materials. } \\
\text { 7. Keep maintaining followers in Instagram. } \\
\text { 8. Responsible in detal for the event such as } \\
\text { prizes, games, rundown, survey paper, } \\
\text { food } 8 \text { beverages, etc. }\end{array}$ \\
\hline Event Coordinator & $\begin{array}{l}\text { 1. Giving any updates about the team work in } \\
\text { each division. } \\
\text { 2. Managing social medla and handbook } \\
\text { content. } \\
\text { 3. Responsible for briefing new volunteers. } \\
\text { 4. Directing graphic designers for appropriate } \\
\text { Illustration and monitoring them due to } \\
\text { deadines. }\end{array}$ \\
\hline Soclal Medla Team & $\begin{array}{l}\text { 1. Creating soclal medla content. } \\
\text { 2. Posting tweets and plctures based on content } \\
\text { calendar. }\end{array}$ \\
\hline $\begin{array}{l}\text { Graphic Designer } \\
\text { Team for Soclal } \\
\text { Media }\end{array}$ & $\begin{array}{l}\text { lilustrating all the contents created by soclal } \\
\text { media team Into images. }\end{array}$ \\
\hline Handoook Team & Content writer of the handbook JOC 2016. \\
\hline $\begin{array}{l}\text { Graphlc Designer } \\
\text { Team }\end{array}$ & $\begin{array}{l}\text { 1. Designing all the promotional ltems: } \\
\text { handbook, goodle bag, t-shirts, Id card, } \\
\text { certificate, e-Invitation, head letter, proposal. } \\
\text { 2. Responsible for any design that needed } \\
\text { urgently except social medla content. }\end{array}$ \\
\hline
\end{tabular}

Source : Data processed by writer, 2016 
PROMOTING ENVIRONMENTAL AWARENESS TO UNDERPRIVILEGED CHILDREN IN JAKARTA BY HOLDING A SPECIAL EVENT "THE JOY OF CHILDREN 2016"

Magdalena Fenisia Caroline \& Anastasia Maria Sri Redjeki

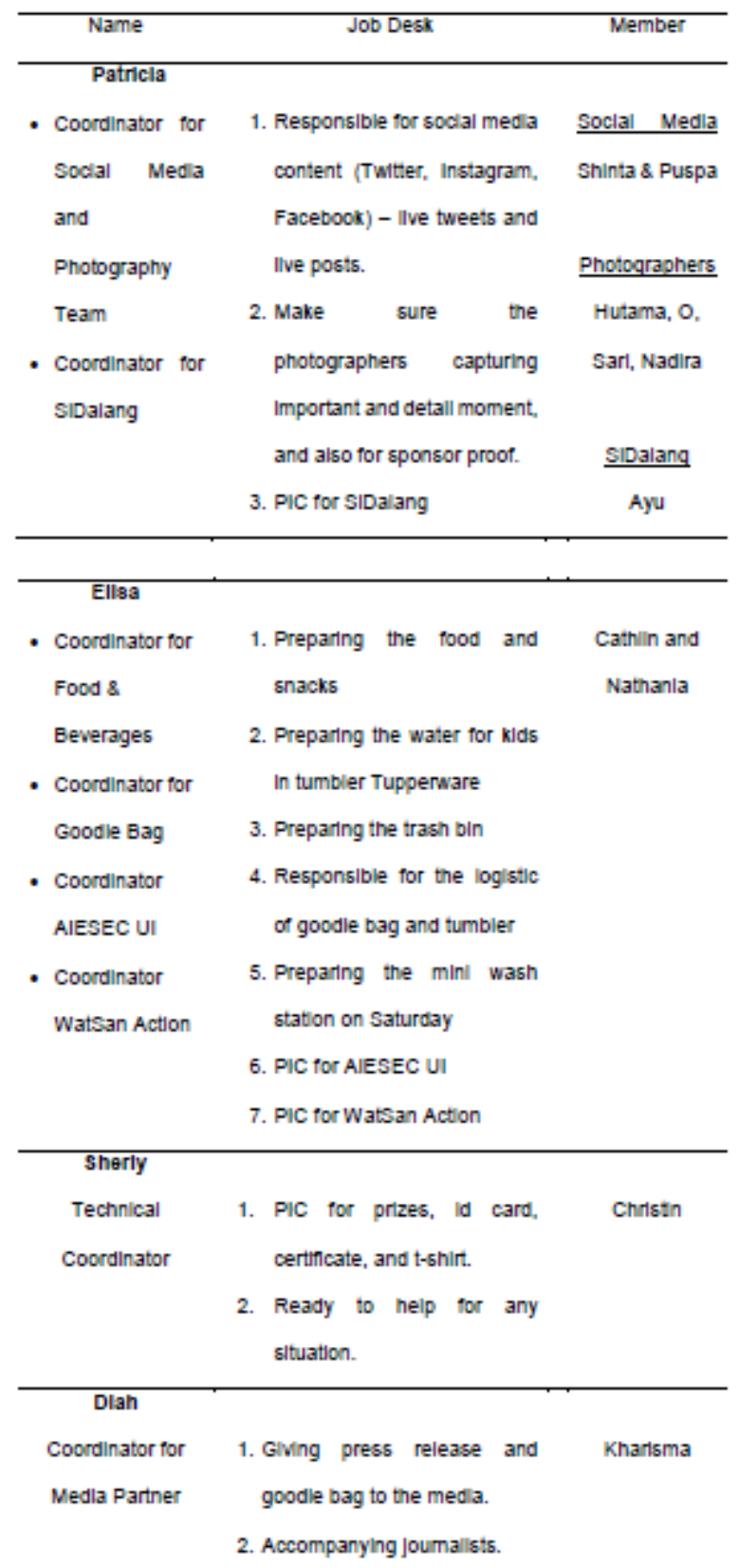




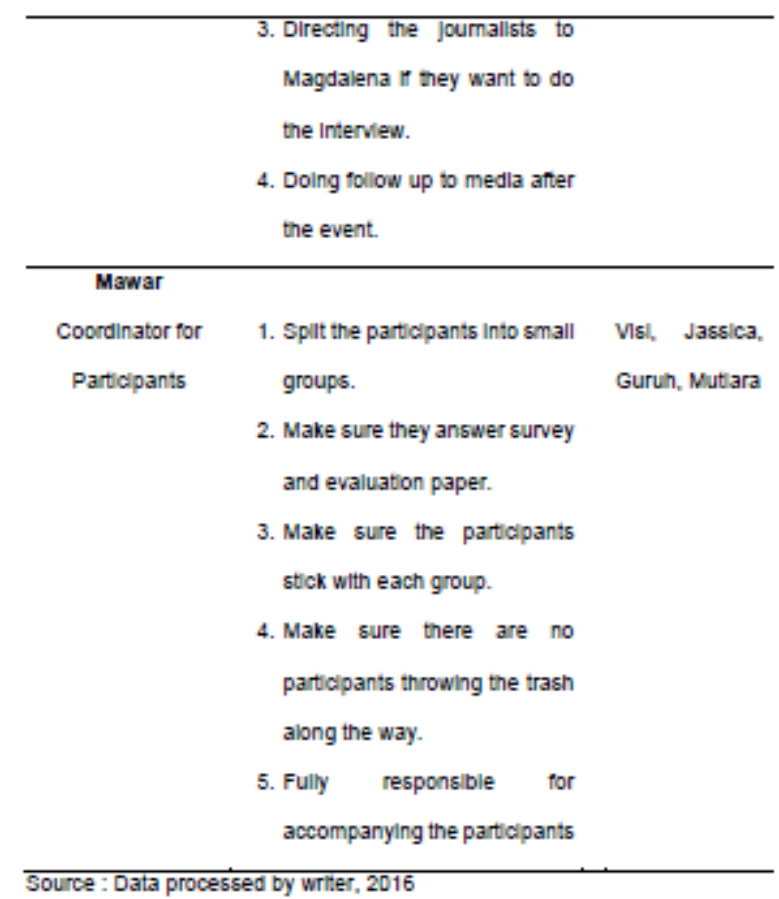

Phase 3: Planning

1. Time

The writer started the project in the beginning of February 2016. The project held on Saturday, 6th August and Sunday, 7th August 2016. The writer had six months' preparation before the event began and one month for post-event to create the project report, media monitoring, and video documentation.

2. Space

a. Saturday, 6th August 2016 - Cakung

The JOC held in the three different spots of outdoor venue for Cakung Children Community at Jalan Cempaka IV No. 16, East Jakarta.

b. Sunday, 7th August 2016 - Cilincing

The JOC held in the Yayasan Putri Kasih Cilincing at Jalan Kalibaru Timur VI-A No. 16, North Jakarta. It is located 5-10 meters from the seaside. There was one activity with WWF Indonesia Panda Mobile that participants went to observe to the sea. The remaining activities was held inside the yayasan.

3. Tempo

The duration from two days' execution of the project was different. On the first day, the event started at 07.00 a.m. and the second day was started at 08.00 a.m. due to annual public activity (senam bersama) in front of the yayasan.

Phase 4: Coordination

1. Community Partners

The JOC ran at the two community partners in Jakarta which are Cakung Children Community and Yayasan Putri Kasih Cilincing. They were taking role as the provider of the participants. On Saturday, 6th August of 2016, the JOC was held at 
Cakung Children Community. There were 25 kids who joined the event from 3rd to 6 th grade of elementary school with range age 9 - 12 years old. Next day, the JOC was held at Yayasan Putri Kasih Cilincing. There were 50 kids who joined the event from 5 th to 6 th grade of elementary school with range age $10-13$ years old.

a. Cakung Children Community (Komunitas Anak Belajar)

It is a learning community for underprivileged children living in East Jakarta. Most of these children come from families of waste picker, driver, greengrocer and labor worker. The community learning center is not big enough for the JOC, therefore it was held in three different spots outside of its place.

b. Yayasan Putri Kasih Cilincing - Pondok Rosalie Rendu

It is a foundation managed by four sisters of Putri Kasih and located approximately five meters from the seaside. The activities done by this foundation focuses on educating children, teaching various skills to women, distributing free groceries every week to the neighborhood and elders, selling cheap used clothes, providing healthcare and services.

\section{Supporting Partners}

Supporting partners in the JOC are the educators to the participants. They take part as the main role of the event. There are WWF Indonesia Panda Mobile, SiDalang (Kreasi Daur Ulang), and WatSan Action - Yayasan Tirta Lestari. These NGOs have their expertise in each field. Besides that, there is one supporting partner who standing not as an educator but only to play with the kids for educational games, which was AIESEC Universitas Indonesia.

a. WWF Indonesia Panda Mobile

Panda Mobile is a part of WWF Indonesia as a media for conservative messenger in public area. They have big truck with the back cabin modified into multifunction stage, library, and a place to watch educational movies. The parties who can invite Panda Mobile are school/university, company, NGO, mall, community, government, and event organizer.

On the second day, Sunday 7th August 2016, Panda Mobile divided 50 kids into three groups. The flow of an activity that was used was a rolling system where each group got the education in three different spots at the same time. Those three spots were the seafront, water lab, and the movie station. The activity that was held at the seafront was the observation on the beach that already not well maintained. There was nothing good aroma around the site due to the garbage scattered as well as being the location of the disposal of the oysters. The facilitators explained to the children about the environmental pollution and its impact to the living things around the location.

Activity at the movie station was playing videos such as the condition of the Ciliwung River which is already polluted and its impact on living creatures. This activity was aimed to let children understand the cycle of waste which 
originated from human behavior to water sources then it will bring bad impact to living creatures.

The rare opportunity of seeing the quality of water through a microscope made participants very enthusiastic on the water lab. They could see a variety of bacteria contained in the water through the screen of the monitor connected to the microscope. Water samples taken from the gutter near the location of the activities. Like the previous day, the children back into one group to hear a fairy tale presented by Kak Ryan and Kak Biyong about the impact of plastic waste on sea life, especially turtles.

b. SiDalang Community (Kreasi Daur Ulang)

SiDalang stands for "Kreasi Daur Ulang" is one of the projects of Tunas Nusa Foundation that was conceived in 2011 in Jakarta. The project is designed to be able to support the three aspects of sustainable development, i.e. environmental, economic and social. They want to bear in mind of the responsibility to corporations and individuals about the production of garbage through the mechanism of waste creation into the qualified craft and ready to sell by a community of moms, teens and children in the selected location.

In this project, SiDalang standing as a waste management educator. They have interactive session with the participants teaching about organic and inorganic garbage and how long does it take to decompose for each type of garbage. After that, the participants follow the workshop to create useful things with waste materials. On Saturday, the participants made money box and pencil case from waste plastic bottles. While on Sunday the participants made postcard from waste cardboard. They were asked to write a personal message about their experience following the JOC's event in the postcard.

c. WatSan Action - Yayasan Tirta Lestari

WatSan Action is a U.S.-based organization founded as an umbrella organization to support Yayasan Tirta Lestari. By working in partnership, they are standing as a non-profit organization addressing water \& sanitation issues. They work with disadvantaged Indonesian communities to improve water \& sanitation conditions through educational activities and participatory projects. Yayasan Tirta Lestari have four programs which are public health promotion program, clean water program, improved sanitation program, solid waste management program.

In this event, they stand as an educator of living in clean and healthy lifestyle. They only came on the second day due to their rule of working hours in the weekend. After the presentation, they sang together with the kids about seven steps to wash hand properly continues with glitter games. The glitter game 
was aimed to tell the kids that bacteria can spread from anywhere only through the hand touching, therefore the kids should wash their hands in a properly way in order to be spared from diseases such as diarrhea. Before the activity ended, WatSan Action - Yayasan Tirta Lestari together with the kids, one-by-one did the seven steps to wash hand properly in the washing station. Once done, each participants got a bath SOAP.

d. AIESEC Universitas Indonesia (UI)

AIESEC UI is the pioneer local committee in Indonesia that was established in 1984. Their role in the event was to give an opportunity to their global volunteers for playing educational games with the participants. They present on the first day only with approximately 15 foreigners and five Indonesian. The games were whisper challenge words games and singing together of "Head, Shoulders, Knees and Toes".

3. Printing Items
a. Paper Bag
b. Handbook
c. T-Shirt
d. ID-Card
e. Certificate
f. Plaque
g. Stickers

4. E-Items

\section{Social Media}

According to Department of Public Information Non-Governmental Organization stated that storytelling through social media content can help create a genuine connection between the audience and the story. By developing a dialogue to encourage two-way communication allows NGOs the opportunity to build dedicated supporters (2013). Therefore, the Joy of Children was being active for daily posting in the four social media platforms which are Facebook, Instagram, Twitter, and LINE@. It was created since 2015 but being actively from the beginning of April to September 2016. To manage the content, the writer created content calendars for Twitter and Instagram to help the team creating content regularly with different and update topics.

By having the social media, the writer has another platform to communicate not only with the target audience of the event, but also to the public whom from middle to high income family background and have social media literacy. 
Facebook of the Joy of Children has 381 likes. Patricia Djuhadi was the admin and she was responsible for posting the posts every day, either images or videos. Facebook has become like a website for the Joy of Children where people only interest to see the photo galleries and information, rather than having interactive session.

Next, the Instagram of the Joy of Children (@thejocproject) with 449 followers now has the highest engagement rate rather than the other social media platforms. There were three admins for Instagram and the working system was every day they should standby online to reply any comments and likes all followers' posts while only one person charged to be the poster. The standby online system divided into three moments; morning; noon; and evening. Example: Puspa responsible for standby in the morning, then Visi in the noon, continue with Novia for the evening. This system was turning roll every day.

The lowest engagement rate of social media platforms JOC is Twitter (@THEJOCPROJECT) with only has 145 followers. The team always posting tweets every day whether kultweets or images.

Lastly, there is a LINE@ of the JOC (@xpz8765v) with219 followers. LINE@ is a service used for distributing information and other business-related goals with sending batch messages to all the followers at once, and also having 1-on-1 chat feature to communicate with them individually. The followers eventually asking about what is JOC doing and how to be involved as a volunteer.

6. Sponsorship

The Joy of Children 2016 was sponsored by PT Citra Van Titipan Kilat (TIKI), PT. Tupperware Indonesia, ERIGO Store, William Soeryadjaya Foundation (WSF), PT Indofood Sukses Makmur Tbk., and PT Tirta Investama (Aqua). The sponsors who gave cash funding were TIKI and WSF with Rp 10.000.000 while Indofood with Rp 7.000.000. Next, the sponsors who gave their products were Tupperware with 150 tumbler and 75 lunch boxes, ERIGO with 150 t-shirts, and Aqua provides 17 gallons of water. All of the sponsors get the same rewards with logo placement in handbook, paper bag, t-shirt, certificate, plaque and e-poster. However, there was only one company, Indofood who asked for eight paper bags, two goodie bags, and five t-shirts.

\section{Media Partnership}

Media partners of the Joy of Children were PT Net Mediatama Televisi (NET TV), kaWanku Magazine, and MRA Media (Mother \& Baby Magazine and CosmoGIRL! Magazine). All of them get the same rewards with logo placement in handbook, paper bag, t-shirt, certificate, plaque and e-poster. 
The journalist team of NET TV came for two days, but the news coverage was only published for the first day of the event. The journalist of Mother \& Baby came on the second day of the event while the journalist of the kaWanku and CosmoGIRL! were not present so the writer sent a press release and documentation to them. In agreement with kaWanku, it is written that they should tweet on the event, but since they did not come, they replaced it by posting two more tweets for @thejocproject.

\section{Phase 5 : Evaluation}

The writer used pre- and post- event survey to the participants. The pre- event survey was done before the event started where the participants need to answer five simple questions.

Table 5

The Result of Pre-event Survey

\begin{tabular}{|c|c|c|c|c|c|c|}
\hline No & Question & Yes & No & Never & Every Day & Sometime \\
\hline 1 & $\begin{array}{l}\text { Do you know about the } \\
\text { role of water? }\end{array}$ & 55 & 20 & & & \\
\hline 2 & $\begin{array}{l}\text { Do you know what is the } \\
\text { difference between } \\
\text { organic and Inorganic } \\
\text { waste? }\end{array}$ & 36 & 39 & & & \\
\hline 3 & How often do you litter? & & & 30 & 24 & 21 \\
\hline 4 & $\begin{array}{l}\text { Does your parent dlspose } \\
\text { the trash into the rlver? }\end{array}$ & 34 & 41 & & & \\
\hline 5 & $\begin{array}{l}\text { Have you ever learnt } \\
\text { about water and } \\
\text { environment pollution at } \\
\text { school? }\end{array}$ & 7 & 68 & & & \\
\hline
\end{tabular}

The post-event survey was done before the team giving the goodie bag and photo session. The participants need to give their opinion by answering three questions which are "Bagaimana kesan kamu mengikuti acara ini? Apa saja yang kamu pelajari dari acara ini? Apa yang akan kamu lakukan sebagai Generasi Pelindung Air?”. Most of them said so happy and excited with this event because now they can differentiate between clean and dirty water, they know how to protect the water and washing their hands properly. They also enjoyed in the movie watching and storytelling session. The participants never thought that sea turtles would eat the plastic waste since it looks like jellyfish. In the end, the writer could analyze through this post-event survey that all the participants were really enjoyed, happy and aware of the water pollution issue by following the event. 


\section{CONCLUSION}

The writer took the conclusion for The Joy of Children 2016 "Generasi Pelindung Air" that special event concept is effective to promote awareness on water pollution issue. It was being held on Saturday, 6th August 2016 at Cakung Children Community for 25 underprivileged kids and Sunday, 7th August 2016 at Yayasan Putri Kasih Cilincing Pondok Rosalie Rendu for 50 underprivileged kids. This event was free and not open for public. Besides of the volunteers, supporting partners, and journalist, there were also sponsor representative from William Soeryadjaya Foundation and TIKI. The writer learnt that special event is useful for non-govermental organization (NGO) to promote idea or cause, acquiring new donors and enhances teamwork in the organization.

The objective of the JOC 2016 is to build awareness of water pollution issue among underprivileged children, so they know and realize if the water gets polluted either by leaking sanitation, domestic wastewater, or floating rubbish, there will be a scarcity of clean water which they will need to buy water with pretty expensive cost. Meiza Saputri, one of the participant, stated that she knows how clean water is really important to her life because sometimes she need to take shower from water well (air sumur). By following the event, she became more aware to not litter at the seaside.

Also with another participant, Reni Oktaviani who get used to buy clean water Rp $10.000,00$ for one hour. After the event, she said she wants to save clean water when using it. In conclusion, the objective of the event was achieved because a lot of positive impression for the event.

However, the participants were much excited until they spent much energy in the beginning of the event, so they were hungry in the middle of the event. It happened both for the two days, when the time for the workshop with SiDalang, most of the children already exhausted and kept screaming for lunch.

After the event, the writer did the evaluation with the team and found out that by volunteering in this event they could learn how to deal with the kids and also being aware about water pollution and environmental issue. So, the objective of the event not only has achieved for the kids but also to the committee. In addition, the writer did media monitoring and creating the project report for sponsors and media partners.

Lastly, the writer published a three-minutes video in personal Facebook account and oneminute video in JOC's Instagram. The purposes of creating this video not only to extend the memories and consistently remind people why they were being part of this event. But also to give additional content for those that are looking up information about the JOC. Putting the video online after the event can be a great way for people to share with others 
so then will increase the popularity of JOC and the viewers might be feeling inspired to take action.

\section{REFERENCES}

Ahlberg, M. (1998). Ecopedagogy and ecodidactics education for sustainable development, good environment and good life. Bulletins of the Faculty of Education, No: 69. University of Joensuu.

Albano, W. Y. (2000). Special Event Planning in the Non-profit Sector (Master thesis). Los Angeles, California: University of Southern California.

Retrieved from http://cdm15799.contentdm.oclc.org/cdm/ref/collection/p15799coll16/id-/34607

Alerts, G. \& Santika, S. S. (1987). Metode Penelitian Air. Surabaya: Usaha Nasional. Retrieved from http://www.tneutron.net/blog/biochemical-oxygen-demand-2/

Apip, Sagala, S.A.H., \& Luo, P. (2015). Overview of Jakarta Water-Related

Environmental Challenges. Retrieved from http://collections.unu.edu/eserv/UNU:2872/WUI_WP4.pdf

Aryanthi, D. (2014). Special Events Concept Marathon Sunrise Yoga to Increase Awareness Jakarta Community and Member of Gold's Gym Jakarta. Undergraduate Dissertation, London School of Public Relations Jakarta, Indonesia.

Bhati, A. (2013). Role of Public Relations for Effective Communications in NGOs. ISSN 2277-8179, Vol. 2, 338-340. Retrieved from http://citeseerx.ist.psu.edu/viewdoc/download?doi=10.1.1.685.9979\&r ep=rep $1 \&$ type $=$ pdf

BPLHD Jakarta. (2013). Laporan Status Lingkungan Hidup Daerah Provinsi

Daerah Khusus Ibukota Jakarta. $\quad$ Retrieved from http://bplhd.jakarta.go.id/SLHD2013/Docs/pdf/Buku\%20I/Buku\%20I\%2 0SLHD\%202013.pdf

BPLHD Jakarta. (2014). Laporan Status Lingkungan Hidup Daerah Provinsi Daerah Khusus Ibukota Jakarta. Retrieved from http://- 
bplhd.jakarta.go.id/SLHD2015/pdf/Buku\%20I/Buku\%20I\%20SLHD\%2

02014.pdf

BPS. (2010). Penduduk Menurut Kelompok Umur dan Jenis Kelamin, Indonesia. $\quad$ Retrieved from http://sp2010.bps.go.id/index.php/site/tabel?tid=336\&wid=0

BPS DKI Jakarta. (2016). Data Jumlah Penduduk Menurut Kelompok Umur dan Jenis Kelamin di Provinsi DKI Jakarta Tahun 2014. Retrieved from http://data.jakarta.go.id/dataset/data-jumlah-penduduk-menurut-kelompokumur-dan-jenis-kelamin-di-provinsi-dki-jakarta/resource/dff58550-4d92-48189f2f-b405b33cf4fc

Caywood, C. L. (1997). The Handbook of Strategic Public Relations \& Integrated Communications. New York: McGraw-Hill Books.

Connor, S. (2014). Microplastic waste: This massive (tiny) threat to sea life is now in every ocean. The Independent. Retrieved from http://goo.gl/0knjHw

Derraik, J. (2002). The pollution of the marine environment by plastic debris: a review. Marine Pollution Bulletin, 44, 842-852. Retrieved from http://caseinlet.org/uploads/Moore--Derraik_1_.pdf

DPI NGO. (2013). Why is Social Media Important for NGOs. Retrieved from http://outreach.un.org/ngorelations/files/2013/12/Why-is-social-mediaimportant-for-NGOs.pdf

Dunlap, R.E \& Jones, R. (2002). Environmental Concern: Conceptual \& Measurement Issues. Handbook of Environmental Sociology by Dunlap \& Michelson. London: Greenwood Press.

Elyda, C. (2016). Aetra invests billions of rupiah to reduce water loss. Jakarta

Post. Retrieved from http://www.thejakartapost.com/-news/2016/02/16/aetrainvests-billions-rupiah-reduce-water-loss.html

EPA. (2016). What is Environmental Education? (Weblog post). Retrieved from https://www.epa.gov/education/what-environmental-education

Getz, D. (2007). Event Studies: Theory, research and policy for planned events. Oxford: Butterworth-Heinemann. 
Goldblat, J. J. (2013). Special Events: Creating and Sustaining a New World for Celebration. New Jersey: John Wiley \& Sons, Inc.

Guth, D. W. \& Marsh, C. (2000). Public Relations: A Values Driven Approach. Needham Heights: Allyn and Bacon.

Hildaje. (2016). Sebagian Warga Masih Bingung dengan Aturan Kantong

Plastik Berbayar. Retrieved from http://tarulh.jakarta.go.id/2016/02/28/sampahplastik-menumpuk/

Iltus, S. (n.d). Climate Change and Environmental Education. Canada: UNICEF. Retrieved from http://www.unicef.org/publications/files/CFS-_Climate_E_web.pdf

Isaac, L. (n.d). The Event Budget. Retrieved from http://www.leoisaac.com/evt/top545.htm

Jamback, J. et al. (2015). Marine Pollution: Plastic waste inputs from land into the ocean. Science, ISSN 1095-9203, 347(6223), 768-771. Retrieved from http://goo.gl/YF4kyr

Kollmuss, A. \& Agyeman, J. (2002). Mind the Gap: why do people act environmentally and what are the barriers to pro-environmental behavior. Environmental Education Research, 8(3), 239-260.

Leibert, E. R. (1972). Handbook of Special Events for Nonprofit Organizations: Tested Ideas for Fund Raising and Public Relations. New York: Hill \& Wang Pub.

Matthews, D. (2008). Special Event Production: The Process. Oxford: Elsevier.

Nugroho, R. (2011). The Governance of the Jakarta Water: The Role of the

Regulatory Body. Retrieved from http://www.academia.edu/5859604/Jakarta_Water_Governance

PRSA. (n.d). About Public Relations. Retrieved from https://www.prsa.org/aboutprsa/publicrelationsdefined/\#.WARDJuCLR dg

Pusat Data dan Informasi. (2011). Situasi Diare di Indonesia (Bulletin). Ministry of Health Indonesia. ISSN 2088 -270X. Retrieved from http://goo.gl/sJHHw9

Retaduari, E. A. (2015). Ini Sampah-sampah Aneh yang Ditemukan di Kali 
Ciliwung. Detik News. Retrieved from http://news.detik.com/berita/2929830/inisampah-sampah-aneh-yang-ditemukan-di-kali-ciliwung

Rupp, Z. (2015). Essay Contest Winner: The Water Crisis. The Seattle Globalist. Retrieved from http://www.seattleglobalist.com/2015/05/23 /essay-contest-winner-thewater-crisis/37299

Said, N. I. (2008). Pengolahan Air Limbah Domestik di DKI Jakarta: Tinjauan Permasalahan, Strategi dan Teknologi Pengolahan. Jakarta: Pusat

Teknologi

Lingkungan.

Retrieved

from

http://www.kelair.bppt.go.id/Publikasi/BukuAir-LimbahDomestikDKI/

Salomon-Lee, C. (2011, July 19). The 5 W's for Inviting Media to Your Event

[Weblog post]. Retrieved from http://www.eventmanagerblog.com/mediapr\#ZEQiorBcwFRSIpgk.99

Sayers, R. (2006). Principles of Awareness-Raising: Information Literacy, A Case Study. Bangkok: Communication and Information.

Shone, A. and Parry, B. (2004). Successful Event Management: A Practical Handbook Second Edition. London: Cengage Learning EMEA.

SPECIAL OLYMPICS IRELAND (n.d). Event Management Guide. Retrieved from http://www.specialolympics.ie/Portals/0/public_documents/Ev_Mgmt_1.8_How_ to_budget_for_your_Event.pdf

STEP. (2014). Coral Reef in Thousand Islands Marine National Park, North Jakarta Indonesia. Retrieved from http://goo.gl/2THZJX

Supriadin, J. (2012). Setiap Hari, Ada 92 Ton Sampah di Laut Jakarta. Tempo. Retrieved from http://m.tempo.co/read/news/2012/11/08/083440585/p-Setiap-HariAda-92-Ton-Sampah-di-Laut-Jakarta

Tambun, L. T. (2015). Djarot: Jakarta Darurat Sampah. Beritasatu.com. Retrieved from http://www.beritasatu.com/megapolitan/273396-djarot-jakarta-daruratsampah-plastik.html

Turney, M. (n.d). Special events generate publicity, but are they effective public relations?. Retrieved from http://www.nku.edu/ turney/prclass-/sections/special_events.html 
Umaly, R. \& M.L.V. Cuvin. (1988). Limnology: Laboratory and field guide, Physicochemical factors, Biological factors. Metro Manila: National

Book Store, Inc. Retrieved from http://www.tneutron.net/blog/biochemical-oxygendemand-2/

UNEP. (n.d). Planning and Management of Lakes and Reservoirs: An Integrated Approach to Eutrophication. Retrieved from http://www.unep.or.jp/ietc/Publications/techpublications/TechPub-11/4-2.asp

UNESCO. (2015). Celebrating 50 years of Water Leadership in Asia and the Pacific: Success Stories from the Field. Jakarta: UNESCO.

Water.orgTM. (n.d.). Facts About Children, Women \& The Safe Water Crisis. Retrieved from http://water.org/water-crisis/women-children-facts/

WHO. (2013). Diarrheal disease (Fact Sheet). Retrieved from http://www.who.int/mediacentre/factsheets/fs330/en/

WHO. (2015). Progress on Sanitation and Drinking Water - 2015 Update and MDG Assessment. ISBN $9789241 \quad 509145 . \quad$ Retrieved from http://apps.who.int/iris/bitstream/10665/177752/1/9789241509145_e ng.pdf

Zakaria, F. (2009). Assessing Pro-Poor Water Supply Programs in Jakarta (Master Dissertation, University of Oxford). Retrieved from https://goo.gl/pyA7Z9 